\title{
Risk of illness and human cost at work in a psychiatric hospitala
}

\author{
Risco de adoecimento e custo humano no trabalho em um hospital psiquiátrico \\ Riesgo de enfermedad y el costo humano en el trabajo en un hospital psiquiátrico
}

Kayo Henrique Jardel Feitosa Sousa ${ }^{1}$ (D)

Danilo de Paiva Lopes ${ }^{1,2}$ (1)

Maria Luiza Figueiredo Nogueira ${ }^{1,3}$ (1)

Gisele Massante Peixoto Tracera $^{1}($ D)

Katerine Gonçalves Moraes ${ }^{1}$ (D)

Regina Célia Gollner Zeitoune ${ }^{1}($ (D)

1. Universidade Federal do Rio de Janeiro.

Rio de Janeiro, RJ, Brasil.

2. Fundação Hospitalar do Estado de Minas Gerais. Belo Horizonte, MG, Brasil.

3. Instituto Nacional de Câncer.

Rio de Janeiro, RJ, Brasil.
Corresponding author:

Kayo Henrique Jardel Feitosa Sousa.

E-mail: kayohenriquejardel@hotmail.com

Submitted on 09/23/2017

Accepted on 04/19/2018.

DOI: 10.1590/2177-9465-EAN-2017-0288

\section{Abstract}

Objective: To investigate the risk of illness and to the human cost at work from the point of view of the nursing team of a psychiatric hospital. Method: A cross-sectional study performed in a psychiatric hospital with 74 nursing workers. The Human Cost of Labor Scale was applied. Results: In the evaluation of the human cost at work, the cognitive cost factor was evaluated as a critical risk for the sickness of the nursing worker, while the factors affective cost and physical cost demonstrated a satisfactory evaluation. The items considered critical for illness referred to: having control of emotions, dealing with the aggressiveness of others, use of vision and memory, and repeated and repeated use of the legs and hands. Conclusion: The evaluated items reveal conditions critical to the health of the nursing worker in mental health, revealing risk of illness.

Keywords: Nursing; Occupational Health; Mental Health.

\section{Resumo}

Objetivo: Investigar o risco de adoecimento e o custo humano no trabalho sob o ponto de vista da equipe de enfermagem de um hospital psiquiátrico. Método: Estudo transversal, realizado em um hospital psiquiátrico, com 74 trabalhadores de enfermagem. Fo aplicada a Escala de Custo Humano no Trabalho. Resultados: Na avaliação do custo humano no trabalho, o fator custo cognitivo foi avaliado como risco crítico para adoecimento do trabalhador de enfermagem, enquanto os fatores custo afetivo e custo físico demonstraram avaliação satisfatória. Os itens considerados críticos para adoecimento referiram-se a: ter controle das emoções, lidar com a agressividade dos outros, uso da visão e memória, uso contínuo e repetido das pernas e mãos. Conclusão: Os itens avaliados indicaram condições críticas para a saúde mental do trabalhador de enfermagem, revelando risco de adoecimento.

Palavras-chave: Enfermagem; Saúde do Trabalhador; Saúde Mental.

\section{Resumen}

Objetivo: Investigar los riesgo de enfermedad y el costo humano en el trabajo desde el punto de vista del equipo de enfermería de un hospital psiquiátrico. Método: Estúdio transversal, realizado en un hospital psiquiátrico, con 74 trabajadores de enfermería. Se aplicó la Escala de Costo Humano en el Trabajo. Resultados: En la evaluación del costo humano en el trabajo, el factor costo cognitivo fue evaluado como riesgo crítico para la enfermedad del trabajador de enfermería, mientras que los factores costo afectivo y costo físico demostraron una evaluación satisfactoria. Los elementos considerados críticos para la enfermedad se refirieron a: tener control de las emociones, tratar con la agresividad de los demás, el uso de la visión y la memoria y el uso continuo y repetido de las piernas y las manos. Conclusión: Los ítems evaluados revelan condiciones críticas para la salud de trabajador de enfermería en salud mental, revelando riesgo de enfermedad.

Palabras clave: Enfermeria; Salud Laboral; Salud Mental. 


\section{INTRODUCTION}

The work that is understood as essentially human activity gives man the ability to transform nature to his usufruct. This activity, once considered more harmonious. However, this form of labor gave way to power and domination by virtue of personal interests. ${ }^{1}$ This domination and centralism in power can provoke emotional tension and somatization, that is, mental processes fail to overcome the burdens experienced, and the impact is felt in the psychic apparatus of the worker. ${ }^{2}$

In order to study the issues related to workers' health, fundamental concepts are used to understand the risk of illness due to work. Among them, the human cost at work is understood as the emotional, physical and cognitive responses imposed by the context. ${ }^{3}$ It is understood that the work context expresses the material, organizational and social locus in which the work is carried out together with the individual mediation strategies and workers' collective visions of this reality, composed of questions concerning the organization and working conditions and socio-professional relations. ${ }^{3}$

In this sense, the worker is required to perform a set of activities, according to specific norms and routines, which he does by means of "tricks"; that is, structures measures in order to overcome the required costs (physical, affective and cognitive) by the contradictions between the work prescribed by the organization and the work performed according to working conditions. $^{4}$

In psychiatric nursing, the main challenges include the search for new ways of caring, aiming at the reorganization of care practice focused on holistic care and centered on the individual, based on interdisciplinarity, deinstitutionalization and social reintegration, in detriment of the biological/organicist view, which proved insufficient to solve the complex issues that surround this field today. ${ }^{5}$ This paradigm change, perhaps, has given rise to new workloads for nursing professionals, with an impact on health conditions and illness of the same.

The Pan American Health Organization (PAHO) has launched a list of priorities for nursing research in Latin America, which includes the subcategory Occupational Health addressing, among several topics, the prevalence and incidence of exposure to risk, occupational diseases and accidents. ${ }^{6}$ The literature is extensive in relation to the investigations that have as object the occupational risks and the sickness related to the work of the nursing team; however, there is a gap in mental health work. The specificity of this locus of practice, which may expose this worker to differentiated risks of illness, and to physical and verbal violence, ${ }^{7,8}$ including racial insult ${ }^{8}$ is highlighted.

This gap has been demonstrated from advanced search in the Latin American and Caribbean Literature in Health Sciences (LILACS) electronic databases, National Library of Medicine NLM (PubMed) and Cumulative Index to Nursing and Allied Health Literature (CINAHL), held on October 2006, using the descriptor "saúde do trabalhador" and its correspondents in
English ("health of the worker"), based on the time cut of the publications of the last five years prior to collection, identifying studies that assessed the risk of illness related to human cost at work in mental health services. However, no published studies were found that approached such subject, as proposed in the present study. However, studies have been identified that have revealed the need for research on the mental health of the nursing worker, since patient safety is directly related to worker safety. ${ }^{5,7,8}$

The present article presents aspects related to nursing work in a psychiatric hospital from the point of view of the risk of illness, aiming at the restructuring of services in the context of the Psychiatric Reform, which deals with the protection and rights of people affected by mental disorders and redirects the mental health care model in Brazil. ${ }^{9}$ Thus, the study aimed to investigate the risk of illness and human cost at work from the point of view of the nursing team of a psychiatric hospital.

\section{METHOD}

This is a cross-sectional and census study carried out in a psychiatric institution in the northeast of Brazil, which provides urgency/emergency, outpatient and psychiatric hospitalization services, serving as a reference for the psychosocial care network in the state and bordering regions. It should be emphasized that this institution is behind the substitutive services implanted in the state, among which are the Psychosocial Care Centers (PSCC), the Therapeutic Residences and the Street Offices.

The population was composed of 90 workers from nursing staff. The inclusion criterion was to participate in the nursing team of the psychiatry service. As exclusion criterion: not being in care service. The workers who met the inclusion criteria were approached in the workplace or by telephone contact, informed about the research and their objectives and invited to participate in the study. All those who accepted the invitation were interviewed in the workplace and signed two copies of the Informed Consent Term (ICT).

Data collection took place in the months of March and April of 2016 through an interview guided by semi-structured script. The results presented here refer to the application of the Human Cost at Work Scale (HCWS), sub-scale of the Inventory on Work and Risk of IIIness (WRI), developed and validated in Brazil. ${ }^{3}$

The HCWS is composed by 32 items, divided into three factors that evaluate the energy expended by the worker in order to overcome the contradictions and obstacles of day to day work in the emotional, intellectual and physical aspects. The factors are: affective cost, cognitive cost and physical cost. It is a five-point Likert scale, where: 1 - not required, 2 - little required, 3 - more or less required, 4 - very required and 5 - fully required. ${ }^{3}$

The data were processed through the Statistical Package for the Social Sciences (SPSS), version 21.0. After correcting for errors and inconsistencies, the analysis was performed. Initially, the individual analysis of each item of the HCWS sub-scale was performed by means of dispersion and variability measures, 
arithmetic mean and standard deviation, respectively. The items were then grouped into HCWS factors and classified as risk of illness, according to the measures cited. The risk of illness was assessed according to the authors' orientation, considering the following means: above 3.70 - more negative evaluation, severe risk of illness; between 3.69 and 2.30 - moderate assessment, critical risk of illness; and below 2.29 - a more positive and satisfactory evaluation. ${ }^{3}$ In order to verify internal consistency, the Cronbach Alpha coefficient was used.

The ethical precepts of research with human beings and all relevant national and international standards were attended; in addition, the research obtained an approval from the Research Ethics Committee, Opinion no. 1,434,109, on March 2 ${ }^{\text {nd }}, 2016$.

\section{RESULTS}

Seventy-four nursing workers participated in the study, equivalent to $82.2 \%$ of the population. The losses corresponded to eight high school level workers who were not located during the data collection period and to two nurses and six nursing technicians who refused to participate in the study. Among those surveyed, 14 were nurses, 16 auxiliaries and 44 nursing technicians; the majority of females $(91.9 \%, \mathrm{n}=68)$; did not live with a partner $(54.1 \%, n=40)$; brown/yellow color $(65.8 \%$, $\mathrm{n}=48)$; did night shifts $(56.8 \%, \mathrm{n}=42)$; weekly workload up to 30 hours $(70.3 \%, n=52)$; without other employment $(54.1 \%$, $\mathrm{n}=40)$; practiced physical activity $(56.8 \%, \mathrm{n}=42)$; had leisure time $(78.4 \%, n=58)$; dissatisfied with sleep $(54 \%, n=40)$. The mean age was 49 years $( \pm 9.22)$ and performance in the service of 17.62 years $( \pm 11.73)$.

The assessment of the internal consistency of HCWS factors showed reliable values. ${ }^{10}$

In the evaluation of the human cost at work, the cognitive cost factor was considered critical for risk of illness, while the affective cost and physical cost factors showed a satisfactory evaluation (Table 1).

As Table 2 shows, in the affective cost the highest risk of illness was related to having control of the emotions and dealing with the aggressiveness of others. In the cognitive cost, only one item had satisfactory evaluation; the items referring to the use of vision and memory received the most critical evaluations for risk of becoming ill. As for the physical cost, only the items related

Table 1. Human cost at work and risk of illness in a psychiatric hospital. Teresina/PI, 2016

\section{HUMAN COST AT WORK}

\begin{tabular}{lcccc} 
FACTOR & Average & SD & $\boldsymbol{\alpha}$ & Risk \\
\hline Affective Cost & 2.24 & 0.660 & 0.772 & Satisfactory \\
\hline Physical Cost & 2.18 & 0.691 & 0.781 & Satisfactory \\
Cognitive Cost & 3.05 & 0.901 & 0.855 & Critical \\
\hline$\alpha$-Cronbach Alfa & & & & \\
\hline
\end{tabular}

to the energy expenditure resulting from the continuous and repeated use of the legs and hands were evaluated as critical to the risk of becoming ill.

\section{DISCUSSION}

The first factor of HCWS is the Affective Cost, understood as "the emotional expenditure, in the form of affective reactions, feelings and state of humor". ${ }^{11: 119}$ In the evaluation of the nursing workers of the institution studied, this factor obtained a positive condition with average below 2.29, denoting an aspect that should be maintained because it favors the health of the worker. It should be noted that in the evaluation of the items that investigate the affective cost, none obtained a classification of severe risk for illness of the worker.

The results of this study are similar to those identified with workers from the Family Health Strategy, ${ }^{12}$ whose evaluation was satisfactory, and diverge from the results found with intensive care nurses, ${ }^{13}$ which were serious for the risk of becoming ill.

The items with the highest averages for this factor were: "having control of emotions", "being forced to deal with aggression from others", "disguising feelings", "having emotional cost", "having to deal with contradictory orders" and "being forced to look after their physical appearance", all of which pose a moderate risk for the worker's illness.

The emotional dimension is an integral part of nursing care, a condition demonstrated by the high averages in items corresponding to the management of emotions. As these are associated with the daily adaptation of the professional to the work, it is necessary, therefore, their recognition and management. ${ }^{14}$

In several situations, the emotional dimension of nursing care emerges, as in the experience of the users of services associated with the phenomena of the health-disease process, the emotional factor associated with their own health-disease experiences, therapeutic interventions, the professional-patient relationship and invasive procedures. ${ }^{15}$ Thus, the inheritance of emotional work to the nursing profession is notorious. This work consists of the personal ability to induce or suppress their own emotions, with the objective of promoting well-being to the other and a safe environment, which also involves the management of the patients' emotions. ${ }^{16} \mathrm{~A}$ study with nursing workers from a substitutive mental health service - Psychosocial Attention Center (PSAC) - identified that because it is a profession that involves personal relationships, emotional control is required and is understandable as soon as the worker develops stress. ${ }^{17}$

In this sense, a study found the difficulty of nurses in the management of emotions in the care of patients with mental disorders, related to the challenges to a good development in the relations with these subjects, since it involves feelings of anguish and impotence in the face of the out of reality results, incapacity and suffering for work. ${ }^{18}$ 
Table 2. Evaluation of risk factors for illness related to human cost at work perceived by nursing workers of a psychiatric hospital. Teresina/PI, 2016

\begin{tabular}{|c|c|c|c|}
\hline & Average & SD & Risk \\
\hline \multicolumn{4}{|l|}{ AFFECTIVE COST } \\
\hline Having control of emotions & 3.34 & 1.388 & Critical \\
\hline Being forced to deal with the aggressiveness of others & 2.96 & 1.359 & Critical \\
\hline Disguising the feelings & 2.74 & 1.385 & Critical \\
\hline Having emotional cost & 2.47 & 1.285 & Critical \\
\hline Having to deal with contradictory orders & 2.46 & 1.252 & Critical \\
\hline Being forced to look after your physical appearance & 2.42 & 1.499 & Critical \\
\hline Transgressing ethical values & 2.20 & 1.462 & Satisfactory \\
\hline Being forced to have a good mood & 2.12 & 1.260 & Satisfactory \\
\hline Being nice to others & 1.92 & 1.156 & Satisfactory \\
\hline Being subjected to constraints & 1.53 & 0.968 & Satisfactory \\
\hline Being forced to smile & 1.41 & 0.905 & Satisfactory \\
\hline Being obliged to praise people & 1.28 & 0.609 & Satisfactory \\
\hline \multicolumn{4}{|l|}{ COGNITIVE COST } \\
\hline Using vision continuously & 3.59 & 1.394 & Critical \\
\hline Using memory & 3.59 & 1.302 & Critical \\
\hline Being forced to deal with the unforeseen & 3.45 & 1.160 & Critical \\
\hline Having mental concentration & 3.43 & 1.335 & Critical \\
\hline Using creativity & 3.19 & 1.331 & Critical \\
\hline Having to solve problems & 2.95 & 1.344 & Critical \\
\hline Making mental effort & 2.78 & 1.530 & Critical \\
\hline Having intellectual challenges & 2.69 & 1.442 & Critical \\
\hline Developing tricks & 2.59 & 1.543 & Critical \\
\hline Foreseeing events & 2.27 & 1.264 & Satisfactory \\
\hline \multicolumn{4}{|l|}{ PHYSICAL COST } \\
\hline Walking & 3.09 & 1.326 & Critical \\
\hline Repeated using of hands & 2.84 & 1.462 & Critical \\
\hline Using the arm continuously & 2.81 & 1.449 & Critical \\
\hline Using legs in continuous forms & 2.54 & 1.445 & Critical \\
\hline Staying in a curved position & 2.16 & 1.147 & Satisfactory \\
\hline Using physical force & 2.07 & 1.174 & Satisfactory \\
\hline Making physical effort & 1.95 & 1.113 & Satisfactory \\
\hline Being forced to stand & 1.86 & 1.162 & Satisfactory \\
\hline Having to handle heavy objects & 1.34 & 0.668 & Satisfactory \\
\hline Going up and down stairs & 1.12 & 0.548 & Satisfactory \\
\hline
\end{tabular}


In this context of health care production, relations are permeated by tensions, conflicts and contradictions, ${ }^{19}$ and also by the distancing of health professionals, users and their families, with emphasis on asylum institutions.

It is salutary to understand that emotional work has not only negative consequences, such as exhaustion, stress, burnout, immunological, cardiovascular and somatic disorders; however, when the professional has the ability to control emotions, positive results are felt in productivity, in the work environment, affective and relational involvement with people, and in professional achievement and satisfaction. ${ }^{21}$

However, a study points out that health workers find it difficult to recognize an emotional management as an institutional policy, making it possible to predict the existence of informality in the management of emotions in relation to the experiences of emotional control established in the relational process. ${ }^{22}$ These difficulties may be related to skills that involve intangible and invisible issues, such as: "giving support and tranquility, sensitivity and kindness, friendliness, encouraging, using humor, having patience, relieving suffering, knowing the client and helping solve their problems". 14:147

A study developed in Portugal points out that several issues are related to the emotional states of health professionals, such as: the neurophysiological, biochemical and personality bases; the instability of patients' health states and the unpredictability of pathological development; fear of complex situations and contexts; the cognitive and affective processes themselves that influence the evaluation of well-being; individual, group and organizational performance; and interpersonal communication. ${ }^{22}$

Another item evaluated by the interviewees of this research and that reflects the process of mental health care refers to the situation of dealing with the aggression of others. This is a constant problem in psychiatric institutions and has been pointed as a stressor in several studies. ${ }^{23-25}$ Violence at work is currently a serious public health problem. It is a growing phenomenon with worrying consequences, with the health sector being a prevalent field of occurrences due to the constant and intense contact and involvement with patients and their families. ${ }^{26}$

A study with employees of a public hospital in the south of Brazil found that $63.2 \%$ of the professionals were victims of some form of violence, showing more prevalent occurrences among female professionals, young and less educated, belonging to the category of nursing auxiliary/technician. The results are still consistent in pointing out that exposure to various forms of violence is a relevant factor to increase the chances of common mental disorder, emotional exhaustion and depersonalization. ${ }^{26}$

Surveys point out that violence at work has effects in the form of somatic symptoms and musculoskeletal damage; ${ }^{27}$ increases the use of psychotropic drugs, particularly antidepressants and anxiolytics; ${ }^{28}$ causes dissatisfaction and lack of motivation with work ${ }^{29}$ and serious mental disorders such as depression, anxiety and post-traumatic stress. ${ }^{30}$
Another issue that moderately contributes to the nursing staff's opinion of the research institution is the fact that they have to deal with contradictory orders. This situation is perceptible when one looks hierarchically at the vertical command line in the nursing team (nurses, technicians and auxiliaries) and among professionals who make up the multiprofessional team. A study with nursing professionals from a university hospital in Paraná has shown that the presence of multiple commands (nurses, physicians, physiotherapists and others) to which the mid-level professionals are subjected is a psychic burden. ${ }^{31}$ It should be said that the act to delegate and supervise the work of the nursing team is necessarily of the nurse. A reality in which you have multiple commands can actually represent a psychic overload.

Another aspect observed in this study was the need to take care of physical appearance. Research on human cost in nursing work in the Intensive Care Unit (ICU) has shown that the good image of an organization's human resources reflects on its ability to ensure organized, safe and effective care. Workers entering the institution are advised on how to present themselves in the ICU, with regard to the personal image - with details about clothing, shoes, hair, nails, adornments and posture -, the non-compliance of which is subject to warnings to the worker. ${ }^{13}$

Cognitive cost is the second factor of the HCWS and refers to "intellectual expenditure for learning, problem solving and decision making at work". ${ }^{11: 119}$ Nursing workers considered that work at the psychiatric institution demands a moderate cognitive cost, which is considered critical, an outcome that is similar to those found by other authors. ${ }^{4 ; 12}$ The results of this study are more positive than those found in another study conducted with nurses of the Intensive Care Unit, which identified a severe cognitive cost for the risk of becoming ill. ${ }^{13}$ No item related to cognitive cost among the 10 evaluated in the present study, obtained a severe evaluation for risk of illness.

The item "forecasting events" presented a satisfactory evaluation. This data meets the need for continuous surveillance, an intrinsic characteristic of work in hospital psychiatric institutions, a factor that makes it difficult for nursing workers to care and to care for themselves. ${ }^{32}$ Study indicates that mental health work requires the worker a permanent state of attention and ability to deal with unforeseen events due to the clinical nature of the patients. Even with the Psychiatric Reform, continuous surveillance and intervening in situations of potential threat to the patient and the community continue to be the primary actions for mental health care. ${ }^{33}$

The unpredictability associated with physical aggressions, manifested in the form of kicks, punches, strangling attempts and slaps intensify the negative effects of continuous surveillance, as the accumulation of energy leads to the development of anxiety, tension and psychosomatic panoramas. ${ }^{33,34}$

These conditions related to unpredictability, in addition to the physical structure with poor adequacy of the lighting level, 
availability of materials, job posts that prevent the visualization of the environment in its totality and consequent perception of important conditions for the patient and the team, are cited as factors which impose the constant use of sight and attention. ${ }^{13}$

With the objective of analyzing the perception of psychosocial factors and mental workload, research with nurses from intensive care units in the central-southern region of Chile showed that, in relation to mental load, factors with cognitive demands, complexity and characteristics of the tasks, showed the highest scores, thus observing that there is a mental overload for the cognitive demands. ${ }^{35}$

Another condition perceived as critical for nursing workers refers to the improvisation of professionals, expressed by the item "developing tricks". This condition still determines the "use of creativity" for the elaboration of means that help to carry out the care in an efficient and effective way.

A qualitative study identified that improvisation and the use of creativity at work are conditions that cause dissatisfaction among workers, as it entails, in addition to loss of energy due to the high degree of attention and time required of the professional to solve structural, material and organizational problems, a time that would be dedicated to the care itself, also affecting the professional satisfaction with the activity performed, mental wear and frustration as their actions are limited. ${ }^{36}$

The physiological and biomechanical expenditure imposed by the characteristics of the work context defines the Physical Cost, the third factor of ECHT. ${ }^{11}$ In the evaluation of the workers of the institution surveyed, this expenditure was evaluated as satisfactory, which refers to a condition of health promotion in the work environment, diverging from the negative results found among intensive care nurses. ${ }^{13}$ Among the 10 items evaluated for physical cost, none obtained a severe evaluation, and only the items "walking", "using hands repeatedly", "using the arm continuously" and "using legs continuously" achieved a critical evaluation for risk of becoming ill.

A study with professionals of the Family Health Strategy revealed that the Physical Cost contributes significantly to the sickness of the worker in this sector. In other words, it is a context of work outside the walls for which the act of walking is crucial, especially to the Community Health Agents who perform daily home visits. Still, it makes a reflection that the continuous, repeated and inadequate use of the hands is due to the insufficiency of materials and inappropriate equipment and the inherent characteristics of the work. ${ }^{12}$

With intensivist nurses, "repeated use of hands", "walking", "being obliged to stand" and "using legs continuously" obtained a serious evaluation for the risk of becoming ill. ${ }^{13}$ In order to justify such results, it was sought to understand that the labor process of the attending nurse essentially involves the manual work, either for preparation and administration of medications, performing procedures and physical examination, hygiene care and feeding. It was pointed out that the need for displacements is a constant, since, in order to obtain inputs for carrying out the activities, it is necessary to walk great distances to the warehouse, pharmacies and depository, still in the provision of care, referrals for exams, among others reasons. ${ }^{13}$

A study evaluating the impact of work for mental health professionals in a psychiatric institution identified a low impact of work, also showing low labor effects on the physical health of the worker, corroborating with the results of the present study. However, $40.6 \%$ of the workers reported that they felt more or less physically tired at the end of the day, and $12.5 \%$ were extremely physically tired. ${ }^{37}$ Research also indicated that physiological and biomechanical loads could be associated with deprivation of sleep and damage to mental health. ${ }^{38}$

A study with nursing professionals from a university hospital in Rio de Janeiro observed that physical exertion, which produces fatigue, manipulation of heavy loads and forced postures to perform some task are ergonomic risk factors for the health of workers in nursing, being frequent in the etiology of Repetitive Strain Injuries/Work-Related Osteomuscular Diseases (RSI/WROD) ${ }^{39}$ For the authors, this data may be associated to the quantitative inadequacy of human resources in nursing within hospital institutions.

A study in Iran found high rates of physical demands among university hospital nurses, being related to lifting weights routinely, transferring patients, and maintaining a bent and uncomfortable posture. ${ }^{40} \mathrm{It}$ also pointed out issues specific to the socioeconomic and cultural context as responsible for the negative effects on the health of nursing staff: the weight of the role of the woman as wife, and mother responsible for the domestic work of the wife; low wages and poor management of staff; the lack of support from the upper hierarchical levels for the management of their roles; the shortage of nursing personnel; and financial cuts in the health sector.

A study with nurses from a surgical clinic of university hospitals in southern Brazil has shown that physical damage is a critical condition for the worker's illness, and therefore requires immediate short- and medium-term measures for the management of biomechanical and physiological requirements in order to promote quality of life, reduction of leave and patient safety. ${ }^{41}$

Physical problems are the main causes of functional readaptation and adjustment, with the following generating situations: movement of patients, transportation of materials and equipment, use of inappropriate furniture and conditions of installation and maintenance of equipment (mechanical loads), in addition to work in shifts, double or triple shift, overtime, overload of activities (physiological loads). ${ }^{42}$

The physiological loads are predominant in reports concerning complaints related to occupational exposure, corroborating with the results cited in the previous studies. Such loads to nursing workers are associated with the manipulation of heavy weights, standing or curved positioning, and the workday. ${ }^{43}$ 
Another important condition that generates wear and tear on the mental health nursing worker is direct, constant and intense contact with the patients. ${ }^{2}$ Nursing professionals perform their tasks in stressful situations that require psychological skills and coping strategies that are not always effective. ${ }^{44}$ Distancing is often interpreted by workers as a way of protecting the tensions provoked by intersubjective exchanges, even in surrogate mental health services, such as PSAC. ${ }^{20}$

A study with nurses showed that psychological damage was directly associated with social and physical damages. ${ }^{41}$ The authors stated that the nature of the work object cannot be altered, but its forms of organization can be modified to control unhealthiness, dangerousness, the painfulness, the exhaustion and the wear and tear of the workers.

Results of a study with workers from a university hospital in the center-west of Brazil corroborate the findings of this study, inasmuch as it showed that the numbers of registered workloads were higher than the number of notifications made, evidencing interaction between two or more loads. ${ }^{43}$ An interesting result, given that the authors consider that the psychic load may be the link with the precarious organization of work and verticalized socio-professional relationships established by the institution.

Nursing is recognized as a fatiguing activity and of great physical, mental and emotional requiring of the worker, added to several factors: shortage of professionals, long shifts and little control over work, inadequate conditions and several other factors that contribute to illness. ${ }^{45}$ This predisposition to illness can partly be due to the high cognitive requirement of the worker, considered as a multipurpose professional, who assumes more and more tasks and is subject to charges, a factor aggravated by the lack of definition of the work object of the nursing professional. ${ }^{13}$ Thus, care in mental health needs the valuation of the nursing worker, since the internal availability of the professional interferes directly in the quality of the care provided. ${ }^{46}$

The limitations of this study refer to the fact that the design is transversal, which only allows the association between variables, but without establishing a cause and effect relationship. The data collection instrument has a national scope, which limited the discussion of the results in the international studies, compromising the comparability of the data. Although it is aimed at workers in general as an initial focus of investigations, it has been shown to be effective ${ }^{13,47}$ when applied to nursing.

Although they present significant results, these cannot be generalized to the population of workers in psychiatric hospitals, since the issues raised are found in other work scenarios of the nursing worker, not specific to psychiatric services, a condition evidenced by the theoretical basis for the data collected for this study. It should also be noted that the data are the opinions of the interviewees, which inhibits the measurement of the instrument, and may constitute an information bias, related to the way it was collected.

\section{CONCLUSION}

The results allow inferring that, although the average scores for the Affective Cost and Physical Cost are satisfactory, the evaluated items reveal critical conditions to the health of the nursing worker in mental health, revealing risk of illness. Cognitive requirements are in the limit situation and demonstrate the inherent characteristic of working in psychiatric hospitals, the state of permanent alert.

\section{REFERENCES}

1. Boff L. Saber Cuidar: ética do humano - compaixão pela terra. $19^{\mathrm{a}} \mathrm{ed}$. Petrópolis: Vozes; 2013. 248 p.

2. Braga FS, Olschowsky A. Pleasure and suffering in the work of mental health nurses in the context of the psychiatric reform. J Nurs UFPE On Line [Internet]. 2015 Mar; [cited 2017 Jul 26]; 9(3):7086-94. Available from: https://periodicos.ufpe.br/revistas/revistaenfermagem/article/ view/10438

3. Mendes AM, Ferreira MC. Contexto de Trabalho. In: Siqueira MMM organizador. Medidas do Comportamento Organizacional: Ferramentas de Diagnóstico e Gestão. Porta Alegre: Artmed; 2008. p. 111-23.

4. Antloga CS, Maia M, Cunha KR, Peixoto J. Contexto de trabalho e custo humano no trabalho em um órgão do poder judiciário brasileiro. Ciênc Saúde Coletiva [Internet]. 2014; [cited 2017 Jul 26]; 19(12):4787-96. Available from: http://www.scielosp.org/pdf/csc/v19n12/1413-8123csc-19-12-04787.pdf

5. Moraes AEC, Almeida Filho AJ, Santos TCF, Peres MAA, Souza MCF, Oliveira AB. Implantação da reforma psiquiátrica no município de Volta Redonda: implicações para a enfermagem. Texto Contexto Enferm [Internet]. $2010 \mathrm{Jul} / \mathrm{Sep}$; [cited 2017 Dec 20]; 19(3):526-35. Available from: http://www.scielo.br/pdf/tce/v19n3/a15v19n3

6. Cassiani SHB, Bassalobre-Garcia A, Reveiz L. Universal Access to Health and Universal Health Coverage: identification of nursing research priorities in Latin America. Rev Latino Am Enferm [Internet]. $2015 \mathrm{Nov} /$ Dec; [cited 2017 Jul 26]; 23(6):1195-208. Available from: http://www. scielo.br/pdf/rlae/v23n6/0104-1169-rlae-10752667.pdf

7. Pekurinen V, Willman L, Virtanen $M$, Kivimäki M, Vahtera J, Välimäk $M$. Patient aggression and the wellbeing of nurses: a cross-sectional survey study in psychiatric and non-psychiatric settings. Int J Environ Res Public Health [Internet]. 2017 Oct; [cited 2017 Dec 26]; 14(10). pii:E1245. Available form: https://www.ncbi.nlm.nih.gov/pubmed/29057802

8. Chandradasa M, Champika L. Racism Toward Mental Health Workers. J Psychosoc Nurs Ment Health Serv [Internet]. 2017 Nov; [cited 2017 Dec 26]; 55(11):5. Available form: https://www.ncbi.nlm.nih.gov/pubm ed/?term=Racism+Toward+Mental+Health+Workers.+Psychosoc+Nu $\mathrm{rs}+$ Ment+Health+Serv

9. Lei № 10.216 de 6 de abril de 2001 (BR). Dispõe sobre a proteção e os direitos das pessoas portadoras de transtornos mentais e redireciona o modelo assistencial em saúde mental. Brasília (DF). 6 de Abr 2001 [cited 4 Jun 2018]. Available from: http://www.planalto.gov.br/ccivil_03/ leis/leis_2001/l10216.htm

10. Cronbach LJ, Gleser GC, Nanda H, Rajaratnam N. The dependability of behavioral measurements: Theory for generalizability of scores and profiles. Science [Internet]. 1972 Dec; [cited 2017 Dec 20] 178(4067):1275-1275A. Available: http://science.sciencemag.org/ content/178/4067/1275

11. Mendes AM, Ferreira MC. Inventário sobre Trabalho e Riscos de Adoecimento - ITRA: instrumento auxiliar de diagnóstico de indicadores críticos no trabalho. In: Mendes AM, org. Psicodinâmica do Trabalho: teoria, método e pesquisas. São Paulo: Casa do Psicólogo; 2007. p. $111-25$. 
12. Shimizu HE, Carvalho Junior DAC. O processo de trabalho na Estratégia Saúde da Família e suas repercussões no processo saúde-doença. Ciênc Saúde Coletiva [Internet]. 2012; [cited 2017 Jul 26]; 17(9):240514. Available from: http://www.scielo.br/pdf/csc/v17n9/a21v17n9.pdf

13. Campos JF, David HMSL. Custo Humano no Trabalho: avaliação de enfermeiros em terapia intensiva à luz da Psicodinâmica do Trabalho. Rev Baiana Enferm [Internet]. 2010 Jan/Dec; [cited 2017 Jul 26]; 24(1):23-32. Available from: https://portalseer.ufba.br/index.php/ enfermagem/article/view/5522/3977

14. Vilelas JMS, Diogo PMJ. Emotional labor in nursing praxis. Rev Gaúcha Enferm [Internet]. 2014 Sep; [cited 2017 Jul 26]; 35(3):145-9. Available from: http://www.scielo.br/pdf/rgenf/v35n3/1983-1447rgenf-35-03-00145.pdf

15. Diogo P, Rodigues L. O trabalho emocional: reflexão e investigação em cuidados de enfermagem. Pensar Enferm [Internet]. 2012; [cited 2017 Jul 26]; 16(1):62-71. Available from: http://pensarenfermagem.esel.pt/ files/PE16-2_Artigo4_62-71(1).pdf

16. Diogo P. O trabalho emocional em enfermagem como foco de investigação e reflexão. Salutis Scientia [Internet]. 2012 Nov; [cited 2017 Jul 26]; 4:1-8. Available from: file:///C:/Users/susana/Downloads/ SS-86.pdf

17. Monteiro ACP, Cruz LML, Dias ACP. Nursing and employee health in a psychiatric institution. Rev Min Enferm [Internet]. 2013 Oct/Dec; [cited 2017 Jul 26]; 17(4):838-45. Available from: http://www.reme.org.br/ artigo/detalhes/890

18. Silva NG, Silva PP, Oliveira AGB. A percepção dos trabalhadores de enfermagem sobre a assistência à saúde mental em hospital universitário. Cienc Cuid Saúde [Internet]. 2012 Apr/Jun; [cited 2017 Jul 26]; 11(2):302-10. Available from: http://periodicos.uem.br/ojs/index. $\mathrm{php} /$ CiencCuidSaude/article/view/11181

19. Cardoso MRO, Oliveira PTR, Piani PPF. Práticas de cuidado em saúde mental na voz dos usuários de um Centro de Atenção Psicossocial do estado do Pará. Saúde Debate (Rio de Janeiro) [Internet]. 2016 Apr/ Jun; [cited 2017 Dec 22]; 40(109):86-99. Available from: http://www. scielo.br/pdf/sdeb/v40n109/0103-1104-sdeb-40-109-00086.pdf

20. Ribeiro MC. Psychosocial care center workers in Alagoas, Brazil: interstices of new practices. Interface (Botucatu) [Internet]. $2015 \mathrm{Jan} /$ Mar; [cited 2017 Dec 22]; 19(52):95-107. Available from: http://www. scielo.br/pdf/icse/v19n52/en_1807-5762-icse-19-52-0095.pdf

21. Vilelas $\mathrm{J} . \mathrm{O}$ trabalho emocional no ato de cuidar em enfermagem: uma revisão do conceito. Salutis Scientia [Internet]. 2013 Mar; [cited 2017 Jul 26]; 5:41-50. Available from: http://www.salutisscientia.esscvp.eu/ Site/Artigo.aspx?artigoid=30974

22. Carvalho CMS, Barata EMMA, Parreira PMSD, Oliveira DC. Trabalho emocional e gestão de emoções em equipes de saúde oncológicas: um estudo qualitativo. Rev Enferm UERJ [Internet]. $2014 \mathrm{Jan} / \mathrm{Feb}$; [cited 2017 Jul 26];22(1):9-15. Available from: http://www.e-publicacoes.uerj. br/index.php/enfermagemuerj/article/view/11356

23. Hamaideh SH. Occupational stress, social support, and quality of life among Jordanian mental health nurses. Issues Ment Health Nurs [Internet]. 2012; [cited 2017 Jul 26]; 33(1):15-23. Available from: https:// www.ncbi.nlm.nih.gov/pubmed/22224962

24. Fernandes MA, Marziale MHP. Occupational risks and illness among mental health workers. Acta Paul Enferm [Internet]. 2014; [cited 2017 Jul 26]; 27(6):539-47. Available from: http://www.scielo.br/pdf/ape/ v27n6/en_1982-0194-ape-027-006-0539.pdf

25. Souza IAS, Pereira MO, Oliveira MAF, Pinho PH, Gonçalves RMDA. Work process and its impact on mental health nursing professionals. Acta Paul Enferm [Internet]. 2015; [cited 2017 Jul 26];28(5):447-53. Available from: http://www.scielo.br/pdf/ape/v28n5/en_1982-0194-ape-28-05-0447.pdf

26. Pai DD, Lautert L, Souza SBC, Marziale MHP, Tavares JP.Violence, burnout and minor psychiatric disorders in hospital work. Rev Esc Enferm USP [Internet]. 2015; [cited 2017 Jul 26]; 49(3):457-64. Available from: http:// www.scielo.br/pdf/reeusp/v49n3/0080-6234-reeusp-49-03-0460.pdf
27. Yang LQ, Spector PE, Chang $\mathrm{CH}$, Gallant-Roman M, Powell J. Psychosocial precursors and physical consequences of workplace violence towards nurses: a longitudinal examination with naturally occurring groups in hospital settings. Int J Nurs Stud [Internet]. 2012 Sep; [cited 2017 Jul 26]; 49(9):1091-102. Available from: https://www. ncbi.nlm.nih.gov/pubmed/22546849

28. Dement JM, Lipscomb HJ, Schoenfisch AL, Pompeii LA. Impact of hospital type II violent events: use of psychotropic drugs and mental health services. Am J Ind Med [Internet]. 2014 Jun; [cited 2017 Jul 26]; 57(6):627-39. Available from: https://www.ncbi.nlm.nih.gov/ pubmed/24526348

29. Batista CB, Campos AS, Reis JC, Schall VT. Violência no trabalho em saúde: análise em unidades básicas de saúde de Belo Horizonte, Minas Gerais. Trab Educ Saúde [Internet]. 2011 Jul/Oct; [cited 2017 Jul 26]; 9(2):295-317. Available from: http://www.scielo.br/pdf/tes/v9n2/08.pdf

30. Gates DM, Gillespie GL, Succop P. Violence against nurses and its impact on stress and productivity. Nurs Econ [Internet]. 2011 Mar/Apr; [cited 2017 Jul 26]; 29(2):59-66. Available from: https://www.ncbi.nlm. nih.gov/pubmed/21667672

31. Secco IAO, Robazzi MLCC, Souza FEA, Shimizu DS. Mental workloads and exhaustion of nursing workers at a teaching hospital in Paraná, Brazil. Rev Eletr Saúde Ment Álcool Drogas [Internet]. 2010; [cited 2017 Jul 26]; 6(1):1-17. Available from: http://www.revistas.usp.br/ smad/article/view/38713

32. Silva AA, Terra MG, Leite MT, Freitas FF, Ely GZ, Xavier MS. Nursing and self-care in the world of psychiatric care. J Res Fundam Care Online [Internet]. 2015 Jan/Mar; [cited 2017 Jul 26]; 7(1):2011-20. Available from: http://www.seer.unirio.br/index.php/cuidadofundamental/article/ view/2887

33. Souza SRC, Oliveira EB, Mauro MYC, Mello R, Kestemberg CCF, Paula GS. Cargas de trabalho de enfermagem em unidade de internação psiquiátrica e a saúde do trabalhador. Rev Enferm UERJ [Internet]. 2015 Sep/Oct; [cited 2017 Jul 26]; 23(5):633-8. Available from: http:// www.facenf.uerj.br/v23n5/v23n5a09.pdf

34. Mendes DP, Moraes GFS, Mendes JCL. Análise da gestão de risco no trabalho de enfermagem em uma instituição psiquiátrica. Trab Educ [Internet].2011 Jan/Apr; [cited 2017 Jul 26];20(1):73-84. Available from: https://seer.ufmg.br/index.php/trabedu/article/view/7088/5464

35. Ceballos-Vásquez P, Rolo-González G, Hérnandez-Fernaud E, DíazCabrera D, Paravic-Klijn T, Burgos-Moreno M. Psychosocial factors and mental work load: a reality perceived by nurses in intensive care units. Rev Latino Am Enferm [Internet]. 2015 Mar/Apr; [cited 2017 Jul 26]; 23(2):315-22. Available from: http://www.scielo.br/pdf/rlae/v23n2/01041169-rlae-23-02-00315.pdf

36. Araújo MPS, Quental LLC, Medeiros SM. Working conditions: feelings of the staff and precariousness of nursing work. J Nurs UFPE On Line [Internet]. 2016 Aug; [cited 2017 Jul 26]; 10(8):2906-14. Available from: https://periodicos.ufpe.br/revistas/revistaenfermagem/article/ view/11359

37. Alves AP, Guidetti GECB, Diniz MA, Rezende MP, Ferreira LA, Zuffi FB Avaliação do impacto do trabalho em profissionais de saúde mental de uma instituição psiquiátrica. Rev Min Enferm [Internet]. 2013 Apr/ Jun; [cited 2017 Jul 26]; 17(2):424-8. Available from: http://www.reme. org.br/artigo/detalhes/660

38. Loro MM, Zeitoune RCG, Guido LA, Silveira CR, Silva RM. Revealing risk situations in the context of nursing work at urgency and emergency services. Esc Anna Nery [Internet]. 2016; [cited 2017 Jul 26] 20(4):e20160086. Available from: http://www.scielo.br/pdf/ean/v20n4/ en_1414-8145-ean-20-04-20160086.pdf

39. Mauro MYC, Paz AF, Mauro CCC, Pinheiro MAS, Silva VG. Condições de trabalho da enfermagem nas enfermarias de um hospital universitário. Esc Anna Nery [Internet]. 2010 Jan/Mar; [cited 2017 Jul 26]; 14(1):13-8. Available from: http://www.scielo.br/pdf/ean/v14n2/05. pdf 
40. Arsalani N, Fallahi-Khoshknab M, Josephson M, Lagerstrom M. Iranian nursing staff's self-reported general and mental health related to working conditions and family situation. Int Nurs Rev [Internet]. 2012 Sep; [cited 2017 Jul 26]; 59(3):416-23. Available from: https://www.ncbi.nlm.nih. gov/pubmed/?term=Iranian+nursing+staff\%E2\%80\%99s+self-report ed+general+and+mental+health+related+to+working+conditions+an $d+$ family+situation

41. Silva RM, Zeitoune RCG, Beck CLC, Martino MMF, Prestes FC. The effects of work on the health of nurses who work in clinical surgery departments at university hospitals. Rev Latino Am Enferm [Internet]. 2016; [cited 2017 Jul 26]; 24:e2743. Available from: http://www.scielo. $\mathrm{br} / \mathrm{pdf} / \mathrm{rlae} / \mathrm{v} 24 / 0104-1169-$ rlae-24-02743.pdf

42. Cacciari P, Haddad MCL, Vannuchi MTO, Dalmas JC. Estado de saúde de trabalhadores de enfermagem em readequação e readaptação funcional. Rev Bras Enferm [Internet]. 2013 Nov/Dec; [cited 2017 Jul 26] 66(6):860-5. Available from: http://www.scielo.br/pdf/reben/v66n6/08. pdf

43. Mininel VA, Felli VEA, Silva EJ, Torri Z, Abreu AP, Branco MTA. Workloads, strain processes and sickness absenteeism in nursing Rev Latino Am Enferm [Internet]. 2013 Nov/Dec [cited 2017 Jul 26];
21(6):1290-7. Available from: http://www.scielo.br/pdf/rlae/v21n6/01041169-rlae-21-06-01290.pdf

44. Zambrano CLM, Diaz HR, Gómez GT, Julio KV. Impacto em lasalud mental de la(del) enfermera(o) que otorga cuidados em situaciones estressantes. Ciênc Enferm [Internet]. 2015; [cited 2017 Jul 26] 21(1):45-53. Available from: http://www.scielo.cl/pdf/cienf/v21n1/art_05. pdf

45. Machado LSF, Rodrigues EP, Oliveira LMM, Laudano RCS, Sobrinho CLN. Agravos à saúde referidos pelos trabalhadores de enfermagem em um hospital público da Bahia. Rev Bras Enferm [Internet]. 2014 Sep/ Oct; [cited 2017 Jul 26]; 67(5):684-91. Available from: http://www.scielo. br/pdf/reben/v67n5/0034-7167-reben-67-05-0684.pdf

46. Tavares CMM, Cortez EA, Muniz MP. Care in psychiatric hospital under the perspective of a nursing team. Rev Rene [Internet]. $2014 \mathrm{Mar} / \mathrm{Abr}$ [cited 2017 Jul 26]; 15(2):282-90. Available from: file:///C:/Users/susana/ Downloads/3141-5861-1-SM.pdf

47. Prestes FC, Beck CLC, Silva RM, Magnago TSBS, Grecco PBT. Human cost in nursing work in a hemodialysis service. Rev Baiana Enferm [Internet]. 2016 Oct/Dec; [cited 2017 Jul 26]; 30(4):1-10. Available from: https://portalseer.ufba.br/index.php/enfermagem/article/view/16440

a Article extracted from the Research Project titled "Factors associated with common mental disorders among nursing workers in a psychiatric hospital".

\section{ERRATUM}

In the article "Risk of illness and human cost at work in a psychiatric hospital", DOI number: 10.1590/2177-9465-EAN-20170288, published in Escola Anna Nery Revista de Enfermagem 2018;22(2):e20170288, "Danilo de Lopes Paiva" should be read as "Danilo de Paiva Lopes". 